\title{
Effect of UV light on pentachlorophenol removal in the electro- Fenton process
}

\author{
Zahra Heidari $^{1}$, Mohsen Motevasel ${ }^{1}$, Nematollah Jaafarzadeh ${ }^{2 *}$ \\ ${ }^{1}$ Department of Chemical Engineering, Petroleum University of Technology, Abadan, Iran \\ ${ }^{2}$ Environmental Technologies Research Center, Ahvaz Jundishapur University of Medical Sciences, Ahvaz, Iran
}

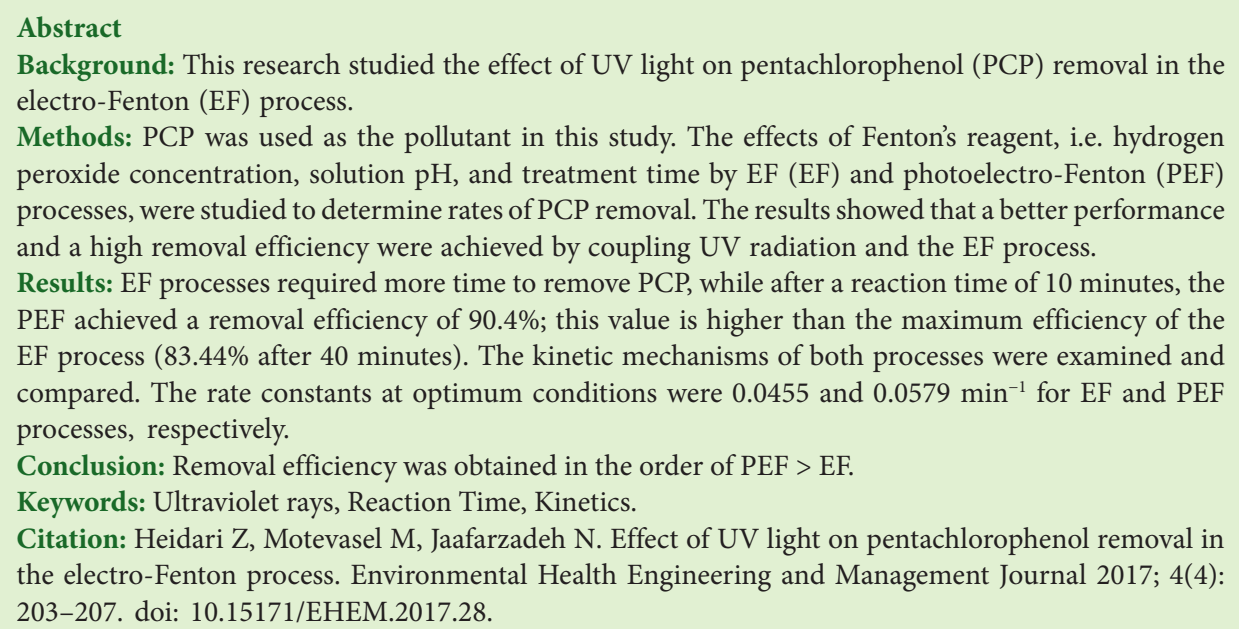

\section{Introduction}

The presence of phenol compounds in the environment has acute toxicity for mankind. Due to five chlorines on the pentachlorophenol (PCP) structure, it is the most toxic agent of chlorophenols (1). PCP can affect the nervous, digestive, and respiratory systems and lead to cancer in humans. It is used in pesticides, disinfectants, and wood preservatives (2). PCP remains in the environment because of the unsuitable disposal of industrial wastes containing PCP and its pertinacity. Thus, the treatment of phenolic pollutants before disposal is very important. It is necessary to find a highly effective method to treat PCP waste (3). Advanced oxidation processes (AOPs) are more efficient than conventional methods. They are able to oxidize and mineralize most organic compounds, including biorecalcitrant ones, by producing highly reactive and nonselective oxidants called hydroxyl radicals ( $\mathrm{HO})(4)$. AOPs include two steps of oxidation: the formation of hydroxyl radicals, and the reaction of these radicals with an organic compound (5).

Conventional biological wastewater treatment processes are inefficient for the removal of recalcitrant organic compounds that are the main sources of pollutants in industrial effluent. The electro-Fenton (EF) process is known as a powerful and environmentally-friendly technology for the removal of this compound from wastewaters (6). In the EF process, highly oxidative hydroxyl radicals are formed from the reaction between $\mathrm{H}_{2} \mathrm{O}_{2}$ and $\mathrm{Fe}^{2+}$ (7). The Fenton process includes the following reactions $(8,9)$ :

$$
\begin{aligned}
& \mathrm{H}_{2} \mathrm{O}_{2}+\mathrm{Fe}^{2+} \rightarrow \mathrm{OH}^{\bullet}+\mathrm{OH}^{-}+\mathrm{Fe}^{3+} \\
& \mathrm{OH} \cdot+\mathrm{RH} \rightarrow \mathrm{R}^{\cdot}+\mathrm{H}_{2} \mathrm{O} \\
& \mathrm{R}^{\cdot}+\mathrm{H}_{2} \mathrm{O}_{2} \rightarrow \mathrm{ROH}+\mathrm{OH}^{\cdot} \\
& \mathrm{OH}^{\cdot}+\mathrm{H}_{2} \mathrm{O}_{2} \rightarrow \mathrm{HO}_{2} \cdot+\mathrm{H}_{2} \mathrm{O} \\
& \mathrm{Fe}^{3+}+\mathrm{HO}^{\circ} \rightarrow \mathrm{Fe}^{2+}+\mathrm{H}^{+}+\mathrm{O}_{2} \\
& \mathrm{Fe}^{2+}+\mathrm{HO}^{\cdot} \rightarrow \mathrm{Fe}^{3+}+\mathrm{HO}^{-} \\
& \mathrm{Fe}^{2+}+\mathrm{OH}^{\cdot} \rightarrow \mathrm{Fe}^{3+}+\mathrm{OH}^{-} \\
& \mathrm{H}_{2} \mathrm{O}_{2}+\mathrm{Fe}^{2+} \rightarrow \mathrm{FeO}^{2+}+\mathrm{H}_{2} \mathrm{O} \\
& \mathrm{FeO}^{2+}+\mathrm{H}_{2} \mathrm{O}_{2} \rightarrow \mathrm{O}_{2}+\mathrm{H}_{2} \mathrm{O}
\end{aligned}
$$

Received: 29 May 2017

Accepted: 5 August 2017 ePublished: 30 August 2017
In the Fenton process $\mathrm{Fe}^{2+}$ is consumed faster than it is produced. The EF method solved this problem by regenerating $\mathrm{Fe}^{2+}$ in the cathode according to the following reaction (10):

$\mathrm{Fe}^{3+}+\mathrm{e}^{-} \rightarrow \mathrm{Fe}^{2+}$ 
The photoelectron-Fenton (PEF) process can regenerate a large amount of $\mathrm{Fe}^{2+}$ by solution irradiation with UV light by the following reaction (11):

$(\mathrm{Fe}-\mathrm{OH})^{2+}+\mathrm{hv} \rightarrow \mathrm{Fe}^{2+}+\mathrm{OH}^{\cdot}$

Furthermore, in the PEF mechanism, hydroxyl radicals can be produced from $\mathrm{H}_{2} \mathrm{O}_{2}$ in the presence of $\mathrm{UV}$ radiation $(11,12)$ :

$\mathrm{H}_{2} \mathrm{O}_{2}+\mathrm{hv} \rightarrow 2 \mathrm{OH}^{\cdot}$

Recently, different usages for the EF process have been found, for example, the treatment of landfill leachate (13), phenol degradation (14), the effect of UV light on acetaminophen degradation in the EF process (15), COD and color removal from landfill leachate (16-18).

According to our previous study $(19,20)$, PCP has been successfully removed in the EF and sonoelectro-Fenton processes, but the effect of UV light on PCP removal in the EF process has not yet been studied. Thus, the current study investigated the effects of UV radiation on PCP removal in the EF process. The influence of operating parameters such as $\mathrm{H}_{2} \mathrm{O}_{2}$ concentration, $\mathrm{pH}$, and treatment time of PCP on degradation was investigated. The reaction kinetics were studied to find the removal mechanism and compare it with the EF results.

\section{Methods}

PCP 98.5\% and $\mathrm{H}_{2} \mathrm{O}_{2}$ (30\%) were purchased from Merck. Sodium sulfate $99.5 \%$ (used as an electrolyte), $\mathrm{H}_{2} \mathrm{SO}_{4}$, and $\mathrm{NAOH}$ were obtained from Merck. Concentrated hydrochloric acid was used for electrode washing. Chemical oxygen demand (COD) was determined using the open reflux method (21). The efficiencies of PCP degradation and COD removal were defined as:

$\mathrm{COD}$ removal efficiency $=\Delta[\mathrm{COD}] / \mathrm{COD}_{0}=\left(\left[\mathrm{COD}_{\mathrm{f}^{-}}\right.\right.$ $\left.\left.\mathrm{COD}_{0}\right] / \mathrm{COD}_{0}\right) \times 100$

where $[\mathrm{COD}]_{0}$ and $[\mathrm{COD}]_{\mathrm{f}}$ are the COD concentrations in the solution at 0 minute and at the end of each reaction, respectively. A divided double-electrode electrochemical cell was used in this study. The reactor was a glass beaker with a volume of $400 \mathrm{~mL}$. The cathodes and anodes of the reactors were a piece of steal (st37). The same experimental set-up as the EF process was used in the photoelectro-Fenton (PEF) process. The addition of eight UVC lamps with a frequency of $247 \mathrm{~nm}$ was used. The $\mathrm{pH}$ of the solutions was adjusted using concentrated sulfuric acid $\left(\mathrm{H}_{2} \mathrm{SO}_{4}\right)$ and sodium hydroxide $(0.1 \mathrm{M})$. A DC power supply used to provide reasonable voltage was connected to the electrodes, and $250 \mathrm{~mL}$ solution was prepared by determining the initial PCP concentration $(15 \mathrm{mg} / \mathrm{L})$ and then adding sodium sulfate as the electrolyte $(2000 \mathrm{mg} / \mathrm{L})$. The initial $\mathrm{pH}$ of the solutions was set. The conductivity of the medium was fixed by adding $\mathrm{Na}_{2} \mathrm{SO}_{4}(2000 \mathrm{mg} / \mathrm{L})$. Then, $250 \mathrm{~mL}$ of sample was transferred to the E-F reactor. After adding the required amount of $\mathrm{H}_{2} \mathrm{O}_{2}$, 8-watt UVC lights were turned on and the PEF experiment was started. The EF set-up was the same as the PEF process but without UV lights.
Results

Figure 1 shows the effect of initial $\mathrm{H}_{2} \mathrm{O}_{2}$ concentration on PCP removal efficiency at a constant PCP concentration of $15 \mathrm{mg} / \mathrm{L}$, voltage of $24 \mathrm{~V}$, and $\mathrm{pH}=3$ after a reaction time of 40 minutes by EF and PEF processes. Under these operational conditions, the PCP removal efficiency rates in both processes were increased with increases in $\mathrm{H}_{2} \mathrm{O}_{2}$ concentration. The effect of $\mathrm{pH}(3-7)$ on PCP removal was studied using both processes, and the results are shown in Figure 2. Experiments were performed using an initial PCP concentration of $15 \mathrm{mg} / \mathrm{L}$, reaction time of 40 minutes, and $\mathrm{H}_{2} \mathrm{O}_{2}$ concentration of $200 \mathrm{~m}$ mole/L. A voltage of $24 \mathrm{~V}$ was maintained for the EF and PEF processes. The effects of treatment time on PCP removal efficiency at an initial PCP concentration of $15 \mathrm{mg} / \mathrm{L}, \mathrm{pH}$ of 3 , and $\mathrm{H}_{2} \mathrm{O}_{2}$ concentration of $200 \mathrm{~m}$ mole/ $\mathrm{L}$ at a voltage of $24 \mathrm{~V}$ in the EF and PEF processes are shown in Figure 3 . In the kinetics study, the zero-, first-, and secondorder models were analyzed separately to determine the behavior of PEF reactions. Modeling of PCP removal by pseudo-first-order, pseudo-second-order, and zero-order equations is shown in Figures 4, 5, and 6, respectively. The results indicate that the removal kinetics followed the

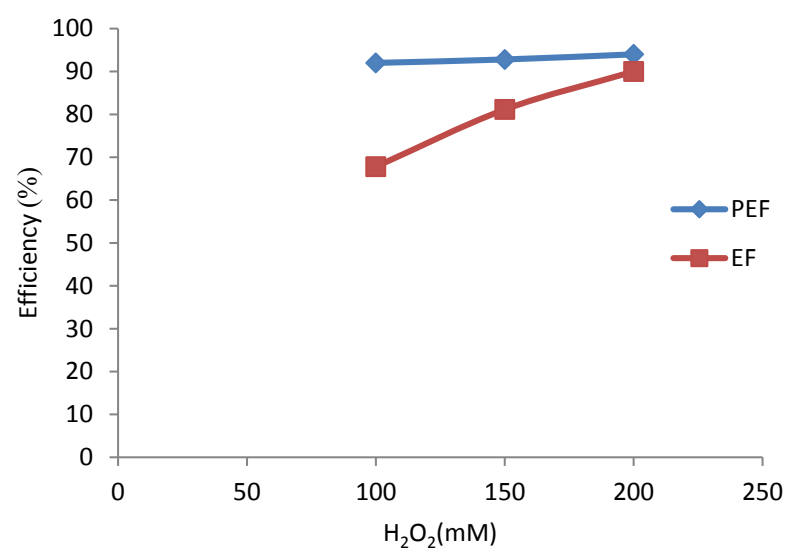

Figure 1. Effect of initial $\mathrm{H}_{2} \mathrm{O}_{2}$ concentration on PCP removal efficiency in the EF and PEF processes.

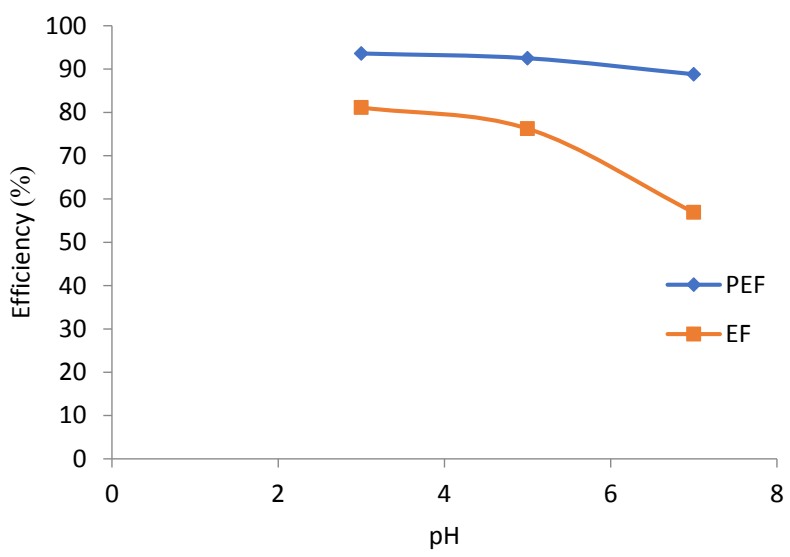

Figure 2. Effect of $\mathrm{pH}$ on PCP removal efficiency in the EF and PEF processes. 
first-order reaction.

\section{Discussion}

Effect of $\mathrm{H}_{2} \mathrm{O}_{2}$ concentration

The highest removal of PCP presented at an $\mathrm{H}_{2} \mathrm{O}_{2}$ concentration of $200 \mathrm{mM}$ in both processes. The maximum

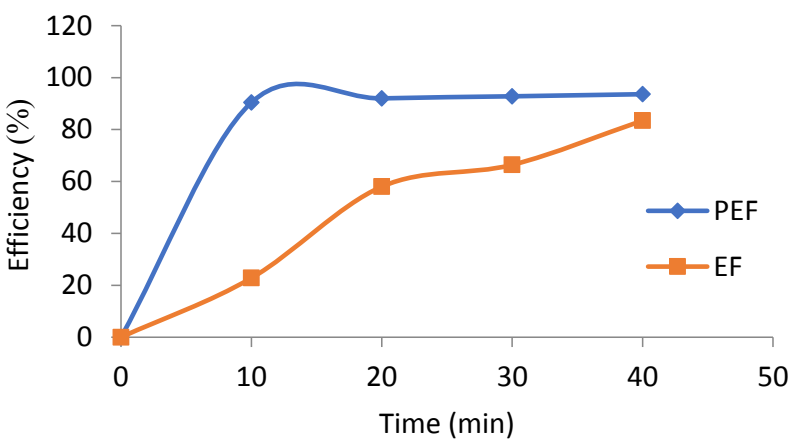

Figure 3. Effect of treatment time on PCP removal efficiency in the EF and PEF processes.

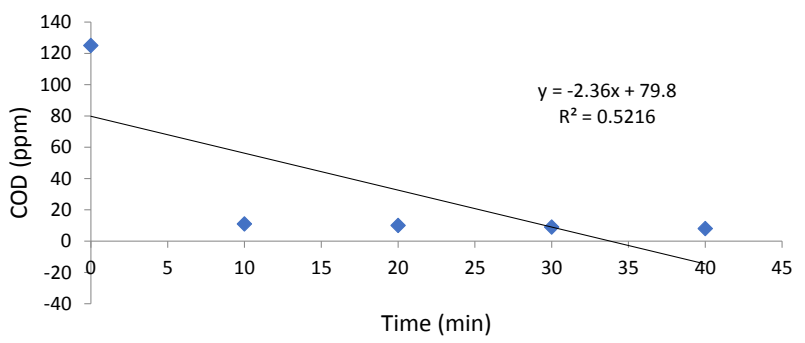

Figure 4. Zero-order kinetics modeling of PCP removal using PEF.

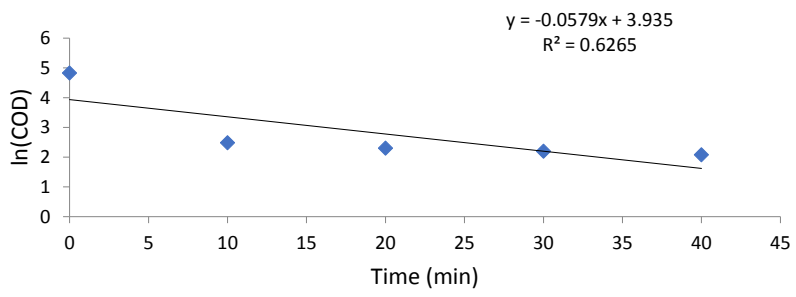

Figure 5. First-order kinetics modeling of PCP removal using PEF.

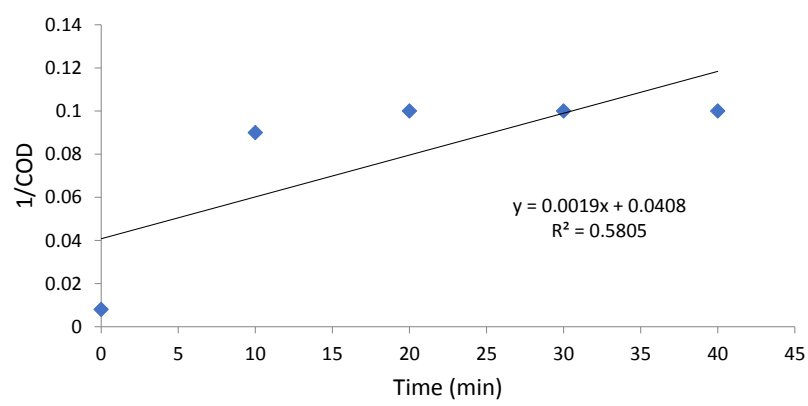

Figure 6. Second-order kinetic modeling of PCP removal using PEF.
PCP removal efficiency of $90 \%$ was observed in the EF process at the $\mathrm{H}_{2} \mathrm{O}_{2}$ concentration of $200 \mathrm{mM}$, while a removal efficiency of $92 \%$ was observed in the PEF at an $\mathrm{H}_{2} \mathrm{O}_{2}$ concentration of $100 \mathrm{mM}$. This phenomenon was due to an $\mathrm{OH} \bullet$ production from reactions 11 and 12 . The difference in PCP removal efficiency was insignificant in the PEF processes. Thus, high efficiency can be achieved by adding the lowest amount of $\mathrm{H}_{2} \mathrm{O}_{2}$ concentration in the $\mathrm{PEF}$ process, and it is economical. In the $\mathrm{AOP}, \mathrm{H}_{2} \mathrm{O}_{2}$ is the main source of hydroxyl radical production according to reaction 1 . The excess amount of $\mathrm{H}_{2} \mathrm{O}_{2}$ has a scavenger effect, so finding the lowest concentration of $\mathrm{H}_{2} \mathrm{O}_{2}$ for higher removal efficiency is very important $(1,10,11,22)$. In the PEF process, UV light reduces the scavenging effect and generates a greater amount of hydroxyl radicals according to Eq. [12] (1). This result was observed in several other studies, including the effect of UV light on acetaminophen degradation in the EF process (10) and treatment of landfill leachate by PEF process (11).

\section{Effect of $\mathrm{pH}$}

It is well known that advanced oxidation reactions occur in low $\mathrm{pH}$ values (13). Hydroxyl radicals have high oxidation ability in acidic mediums (1). The results showed that PCP removal efficiency is significantly affected by $\mathrm{pH}$. The maximum PCP removal was observed at $\mathrm{pH} 3$ (93.6\% in PEF process). Increasing $\mathrm{pH}$ from 3 to 7 reduced the amount of PCP removed for both process. This is due to the reduction in hydroxyl oxidation potential in high $\mathrm{pH}$ values. At high $\mathrm{pH}$ values, ferric hydroxide was formed and caused the low generation of hydroxyl radicals $(1,20)$. At higher $\mathrm{pH}$ values, electro-coagulation starts in the reactor because of the conversion of $\mathrm{Fe}^{2+}$ and $\mathrm{Fe}^{3+}$ to $\mathrm{Fe}(\mathrm{OH})$ n-type structures $(1,13)$. Increasing $\mathrm{pH}$ to a value beyond 3 affected the removal efficiency because of the transformation of ferrous ions $\left(\mathrm{Fe}^{2+}\right)$ to ferric iron $\left(\mathrm{Fe}^{3+}\right)$. By adding UV light radiation to the EF process, it is possible to reduce $\mathrm{Fe}^{3+}$ to $\mathrm{Fe}^{2+}$ and generate hydroxyl radicals according to the following reaction (3):

$\mathrm{Fe}(\mathrm{OH})^{2+h v} \rightarrow \mathrm{Fe}^{2+}+{ }^{\cdot} \mathrm{OH}$

Hydroxyl radicals produced in these reactions are used for PCP removal at higher $\mathrm{pH}$ values. In this situation, $\mathrm{PEF}$ processes could be used at a near neutral $\mathrm{pH}$ and reduce the problems created by acidic effluent treatment (1). This result was observed in several other studies, including advanced oxidation of phenol by EF and SEF process (1), COD and color removal from synthetic textile wastewater by SEF process (22), and PCP removal by SEF (20).

\section{Effect of treatment time}

As shown in Figure 3, the PCP removal efficiency of the $\mathrm{EF}$ and PEF processes was increased by increasing the reaction time; in the PEF process, a removal efficiency of $90.4 \%$ was obtained after a reaction time of 10 minutes; this value is higher than the maximum efficiency of the EF process (83.44\% after 40 minutes). These phenomena 
can be a result of the greater amount of hydroxyl radical produced, according to Eq. [12] (1). In the studies of Babuponnusami et al (1), and Altin (11), similar results were observed.

Kinetics of pentachlorophenol removal

According to our previous studies, the removal of PCP by the EF process can be represented as (20):

$\mathrm{PCP}+\mathrm{OH} \bullet \rightarrow$ Oxidation products

As described in our previous study, the zero-order, firstorder, and second-order reaction kinetics, respectively, can be written as shown below, and the removal of PCP by the EF process followed the pseudo-first-order kinetics (20):

\section{$\mathrm{C}=\mathrm{C} 0-\mathrm{k} 0 \mathrm{t}$}

$\ln \mathrm{C}-\ln \mathrm{C}_{0}=-\mathrm{k}_{\text {app }} \mathrm{t}$

$1 / \mathrm{C}=1 / \mathrm{C} 0-\mathrm{Kt}$

The correlation coefficients for the PCP removal kinetics of zero-, pseudo-first, and second order were 0.5216, 0.6265 , and 0.5805 , respectively. The comparison of the correlation coefficients indicated a good agreement between the removal kinetics and the pseudo-first order models. The results of zero-, first-, and second-order reaction kinetics for PCP removal in EF and PEF processes are summarized in Table 1.

Figure 7 shows the comparison of the results of the first-order kinetics models for both the EF and the PEF method, and it shows that the rate constants of the EF and PEF processes are 0.0455 and 0.0579 , respectively. The same results were reported by other studies $(1,10,20)$.

\section{Conclusion}

This study investigated the effects of UV radiation combined with EF for the removal of PCP from aqueous solutions. The results indicated that both the EF and PEF

Table 1. The regression coefficients for zero-, first-, and secondorder kinetics

\begin{tabular}{lccc}
\hline Oxidation process & Zero-order & First-order & Second-order \\
\hline EF & 0.9045 & 0.9707 & 0.9418 \\
PEF & 0.5216 & 0.6265 & 0.5805 \\
\hline
\end{tabular}

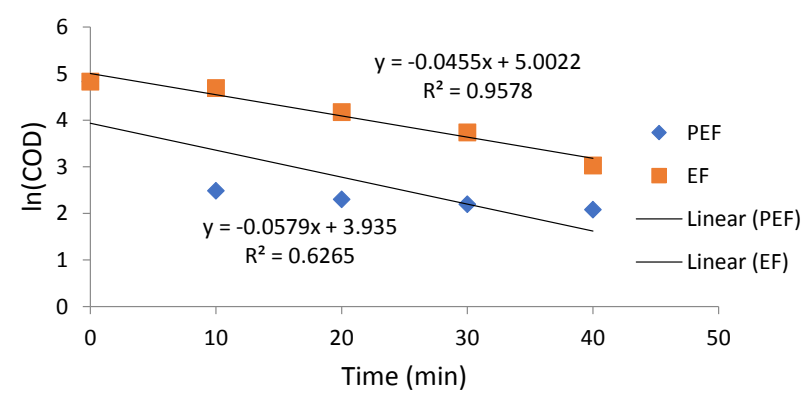

Figure 7. Pseudo-first-order kinetics plot under the EF and PEF processes under optimum conditions $\left(\mathrm{H}_{2} \mathrm{O}_{2}=200 \mathrm{mM}\right.$, voltage $=$ $24 \mathrm{~V}, \mathrm{PCP}=15 \mathrm{mg} / \mathrm{L}$, and $\mathrm{pH}=3$ ) processes were effective in removing PCP from wastewater. The effects of changing the $\mathrm{H}_{2} \mathrm{O}_{2}$ concentration was clearer in the PEF process than in the EF process. At low $\mathrm{H}_{2} \mathrm{O}_{2}$ injection amounts, adding UVA irradiation enhanced the PCP removal rate in the PEF process because of the greater production of $\mathrm{OH} \bullet$ in the PEF process. Another advantage of combining UV and EF was that it could act at high $\mathrm{pH}$ values near the neutral $\mathrm{pH}$ and solve the problems associated with acidic effluent. From the kinetic studies, both processes followed the first-order reaction. The rate constant values at optimum conditions were equal to 0.0455 and $0.0579 \mathrm{~min}^{-1}$ for the EF and PEF processes, respectively. The following items are recommended as subjects for further research: studying the efficiency of PCP removal from aqueous solutions by sequential sono-photoelecro-Fenton; repeating this process for real wastewater.

\section{Acknowledgments}

The authors would like to thank the Petroleum University of Technology for providing financial support for this study.

\section{Ethical issues}

The authors have thoroughly observed ethical issues, including plagiarism, misconduct, data fabrication, and redundancy.

\section{Competing interests}

The authors declare that no competing interests exist.

\section{Authors' contributions}

All authors contributed equally to the study, and all authors participated in data acquisition, analysis, and interpretation. All authors critically reviewed, refined, and approved the manuscript.

\section{References}

1. Babuponnusami A, Muthukumar K. Advanced oxidation of phenol: A comparison between Fenton, electro-Fenton, sono-electro-Fenton and photo-electro-Fenton processes. Chem Eng J 2012; 183: 1-9. doi: 10.1016/j.cej.2011.12.010.

2. Kumar Y, Popat KM, Brahmbhatt H, Ganguly B, Bhattacharya A. Pentachlorophenol removal from water using surfactant-enhanced filtration through low-pressure thin film composite membranes. J Hazard Mater 2008; 154(1-3): 426-31. doi: 10.1016/j.jhazmat.2007.10.060.

3. Zhang J, Ye P, Chen S, Wang W. Removal of pentachlorophenol by immobilized horseradish peroxidase. Int Biodeterior Biodegradation 2007; 59(4): 307-14. doi: 10.1016/j.ibiod.2006.09.003.

4. Moreira FC, Vilar VJP, Ferreira ACC, dos Santos FRA, Dezotti M, Sousa MA, et al. Treatment of a pesticidecontaining wastewater using combined biological and solar-driven AOPs at pilot scale. Chem Eng J 2012; 209 : 429-41. doi: 10.1016/j.cej.2012.08.009.

5. Amri N, Nasuha N, Halim SFA, Ngah K. Degradation of Reactive Black 5 dye by CWPO using Fe/mining sand 
under photo-Fenton process. AIP Conference Proceedings 2015; 1660(1): 070094. doi: 10.1063/1.4915811.

6. Nidheesh PV, Gandhimathi R. Trends in electroFenton process for water and wastewater treatment: An overview. Desalination 2012; 299: 1-15. doi: 10.1016/j. desal.2012.05.011.

7. Huang YH, Chou S, Perng MG, Huang GH, Cheng SS. Case study on the bioeffluent of petrochemical wastewater by electro-fenton method. Water Sci Technol 1999; 39(10-11): 145-9. doi: 10.1016/S0273-1223(99)00265-6.

8. Neyens E, Baeyens J. A review of classic Fenton's peroxidation as an advanced oxidation technique. J Hazard Mater 2003; 98(1-3): 33-50. doi: 10.1016/S0304-3894(02)00282-0.

9. Ma J, Song W, Chen C, Ma W, Zhao J, Tang Y. Fenton Degradation of Organic Compounds Promoted by Dyes under Visible Irradiation. Environ Sci Technol 2005; 39(15): 5810-5. doi: 10.1021/es050001x.

10. Jaafarzadeh N, Ghanbari F, Ahmadi M, Omidinasab M. Efficient integrated processes for pulp and paper wastewater treatment and phytotoxicity reduction: Permanganate, electro-Fenton and Co3O4/UV/peroxymonosulfate. Chem Eng J 2017; 308: 142-50. doi: 10.1016/j.cej.2016.09.015.

11. Altin A. An alternative type of photoelectro-Fenton process for the treatment of landfill leachate. Sep Purif Technol 2008; 61(3): 391-7. doi: 10.1016/j.seppur.2007.12.004.

12. Ruiz EJ, Hernández-Ramírez A, Peralta-Hernández JM, Arias C, Brillas E. Application of solar photoelectro-Fenton technology to azo dyes mineralization: Effect of current density, Fe2+ and dye concentrations. Chem Eng J 2011; 171(2): 385-92. doi: 10.1016/j.cej.2011.03.004.

13. Atmaca E. Treatment of landfill leachate by using electroFenton method. J Hazard Mater 2009; 163(1): 109-14. doi: 10.1016/j.jhazmat.2008.06.067.

14. Pimentel M, Oturan N, Dezotti M, Oturan MA. Phenol degradation by advanced electrochemical oxidation process
electro-Fenton using a carbon felt cathode. Appl Catal B 2008; 83(1): 140-9. doi: 10.1016/j.apcatb.2008.02.011.

15. Su CC, Cada CA, Dalida MLP, Lu MC. Effect of UV light on acetaminophen degradation in the electro-Fenton process. Sep Purif Technol 2013; 120: 43-51. doi: 10.1016/j. seppur.2013.09.034.

16. Daud Z, Hanafi NFM, Awang H. Optimization of COD and Colour Removal from Landfill Leachate by Electro-Fenton Method. Aust J Basic Appl Sci 2013; 7(8): 263-8.

17. Peralta-Hernández JM, Martínez-Huitle CA, GuzmánMar JL, Hernandez-Ramirez A. Recent Advances in the application of electro-Fenton and photoelectro-Fenton process for removal of synthetic dyes in waste water treatmen. J Environ Eng Manage 2009; 19(5): 257-65.

18. Özcan A, Şahin Y, Oturan MA. Complete removal of the insecticide azinphos-methyl from water by the electroFenton method - A kinetic and mechanistic study. Water Res 2013; 47(3): 1470-9. doi: 10.1016/j.watres.2012.12.016.

19. Heidari Z, Motavasel M, Jaafarzadeh N. Application of Electro-Fenton (EF) process to the removal of pentachlorophenol from aqueous solutions. Iranian Journal of Oil Gas Science and Technology 2015; 4(4): 76-87. doi: 10.22050/ijogst.2016.12481

20. Heidari Z, Motevasel M, Jaafarzadeh N. Advanced oxidation of pentachlorophenol: A comparison between electro-Fenton, sono electro-Fenton processes. American Journal of Oil and Chemical Technologies 2017; 5(2): 1419. doi: 10.1016/j.cej.2011.12.010.

21. APHA. Standard Method for Examination of Water and Wastewater. 17th ed. Washington, DC: American Public Health Association; 1989.

22. Şahinkaya S. COD and color removal from synthetic textile wastewater by ultrasound assisted electro-Fenton oxidation process. Ind Eng Chem 2013; 19(2): 601-5. doi: 10.1016/j. jiec.2012.09.023. 